\title{
Whole exome sequencing identified a novel zinc-finger gene ZNF141 associated with autosomal recessive postaxial polydactyly type $\mathrm{A}$
}

\author{
Umm-e- Kalsoom, ${ }^{1,2}$ Eva Klopocki, ${ }^{2}$ Naveed Wasif, ${ }^{3}$ Muhammad Tariq, \\ Saadullah Khan, ${ }^{1}$ Jochen Hecht, ${ }^{4}$ Peter Krawitz, ${ }^{2}$ Stefan Mundlos, ${ }^{2,4,5}$ Wasim Ahmad ${ }^{1}$
}

\begin{abstract}
- Additional supplementary data are published online only. To view this file please visit the journal online (http://dx.doi. org/10.1136/jmedgenet-2012101219).

'Department of Biochemistry, Quaid-i-Azam University Islamabad, Islamabad, Pakistan ${ }^{2}$ Institute for Medical and Human Genetics, Charite Universitatsmedizin Berlin, Berlin, Germany

${ }^{3}$ Center for Research in Molecular Medicine, Institute of Molecular Biology and Biotechnology, The University of Lahore, Lahore, Punjab, Pakistan

${ }^{4}$ Max Plank Institute for Molecular Genetics, Berlin, Germany

${ }^{5}$ Berlin-Brandenburg Center for Regenerative Therapies (BCRT), Charite Universitatsmedizin Berlin, Berlin, Germany
\end{abstract}

\section{Correspondence to}

Dr Wasim Ahmad,

Department of Biochemistry, Faculty of Biological Sciences, Quaid-i-Azam University Islamabad, Pakistan, 4400; wahmad@qau.edu.pk

Received 8 August 2012 Revised 14 October 2012 Accepted 15 October 2012 Published Online First 17 November 2012

To cite: Kalsoom U-eKlopocki E, Wasif N, et al. J Med Genet 2013, 50. 47-53.

\section{ABSTRACT}

Background Postaxial polydactyly (PAP) type $A$ is characterised by well-formed functionally developed 5 th digit duplication in hands and/or feet. It is genetically heterogeneous condition, inherited both in autosomal recessive and dominant manners. To date one autosomal recessive and four autosomal dominant loci have been mapped on human chromosomes. In the present study we have investigated a consanguineous Pakistani family segregating autosomal recessive PAP type A to identify the gene responsible for this phenotype.

Methods Whole exome sequencing combined with homozygosity mapping and array comparative genomic hybridisation $(\mathrm{aCGH})$ analysis was used to search for a genetic cause of PAP type $A$ in the present study.

Results Exome sequencing identified a missense mutation (c.1420C>T; p.Thr474lle) in all the affected individuals of the family, in the gene ZNF141, mapped to the telomeric region on chromosome $4 p 16.3$.

Conclusion This study revealed involvement of a zinc finger gene ZNF141 in causing autosomal recessive PAP type $A$, which may open up interesting perspectives into the function of this protein in limb development.

\section{INTRODUCTION}

Pentadactyly is the characteristic feature, inherited by all the modern tetrapods from their ancestors, although many species have reduced the number of digits or even lost the limbs. ${ }^{12}$ Despite the multiple variations on the basic pentadactylous pattern, a limit of five in the number of digits appears to be constant. Variation in this number can cause multiple digital deformities. The major types of digital deformities are polydactyly (digit duplication) and syndactyly (fusion of soft tissues and/or bones). According to the location of an extra digit, there exist three categories of polydactyly: preaxial (radial side) polydactyly characterised as an extra thumb or large toe deformity, central polydactyly and postaxial (ulnar side) polydactyly (PAP) with an extra little finger or toe. ${ }^{3}$ The extra digit ranges from a rudimentary structure to a fully developed and functional ray and can be an isolated finding or part of a genetic syndrome. ${ }^{4-6}$ Biesecker, ${ }^{7}$ compiled a list comprising of 310 disorders (syndromic, 290 entries and nonsyndromic 20 entries) with polydactyly, of which 80 disorders are associated with mutations in a total of 99 genes.

The aetiology and pathogenesis of polydactyly is incompletely understood, but evidence suggests that the more common isolated occurrences of polydactyly are inherited as an autosomal dominant condition with variable penetrance. Four genetic loci are known for autosomal dominant PAP: PAP1 on $7 \mathrm{p} 13$ caused by mutation in GLI3 gene, ${ }^{8} 9$ PAP2 on $13 \mathrm{q} 21-\mathrm{q} 32,{ }^{10}$ PAP3 on $19 \mathrm{p} 13.1-13.2^{11}$ and $7 \mathrm{q} 21-\mathrm{q} 34 .^{12}$

Recently we reported mapping of the first locus of autosomal recessive PAP type A in a consanguineous Pakistani family on chromosome 13q13.3q21.2. ${ }^{13}$ Here, we present a second consanguineous Pakistani family segregating PAP type A. Whole exome sequencing (WES) identified a missense mutation (c.1420C>T; p.Thr474Ile) in the zinc finger gene ZNF141 located on the chromosome $4 \mathrm{p} 16.3$.

\section{METHODS}

\section{Family history}

A consanguineous family, segregating autosomal recessive PAP type A was sampled from the Punjab province of Pakistan. The pedigree (figure 1) provided convincing evidence of an autosomal recessive mode of inheritance of the PAP type A. The four affected individuals (V-1, V-2, V-3, V-4) of the family were carefully examined at the local government hospital and no additional phenotype other than PAP type A was observed. The study was approved by Institutional Review Board (IRB) of Quaid-i-Azam University, Islamabad, Pakistan. Venous blood samples were collected from four affected (V-1, V-2, V-3, V-4) and five unaffected individuals (IV-1, IV-2, V-5, V-6, V-7). Informed written consent for the study, including presentation of photographs for publication, was obtained from affected individuals and their parents.

\section{Whole Exome Sequencing (WES)}

Family members V-1, V-2, and V-4 were subjected to WES. For each sample, $4 \mu \mathrm{g}$ of genomic DNA was enriched for the target region of all human the consensus coding sequence (CCDS) exons ${ }^{14}$ with Agilent's SureSelect Human All Exon Kit V2 and subsequently sequenced on Illumina Genome Analyzer II with $100 \mathrm{bp}$ single end reads. The raw data of $\sim 5 \mathrm{~GB}$ per Exome was mapped to the haploid human reference sequence hg 19 with Novoalign. ${ }^{15}$ Single nucleotide variants and short insertions and deletion were detected with SAMtools. ${ }^{16}$ All variants were annotated with annovar $^{17}$ and filtered using GeneTalk. ${ }^{18}$ The 


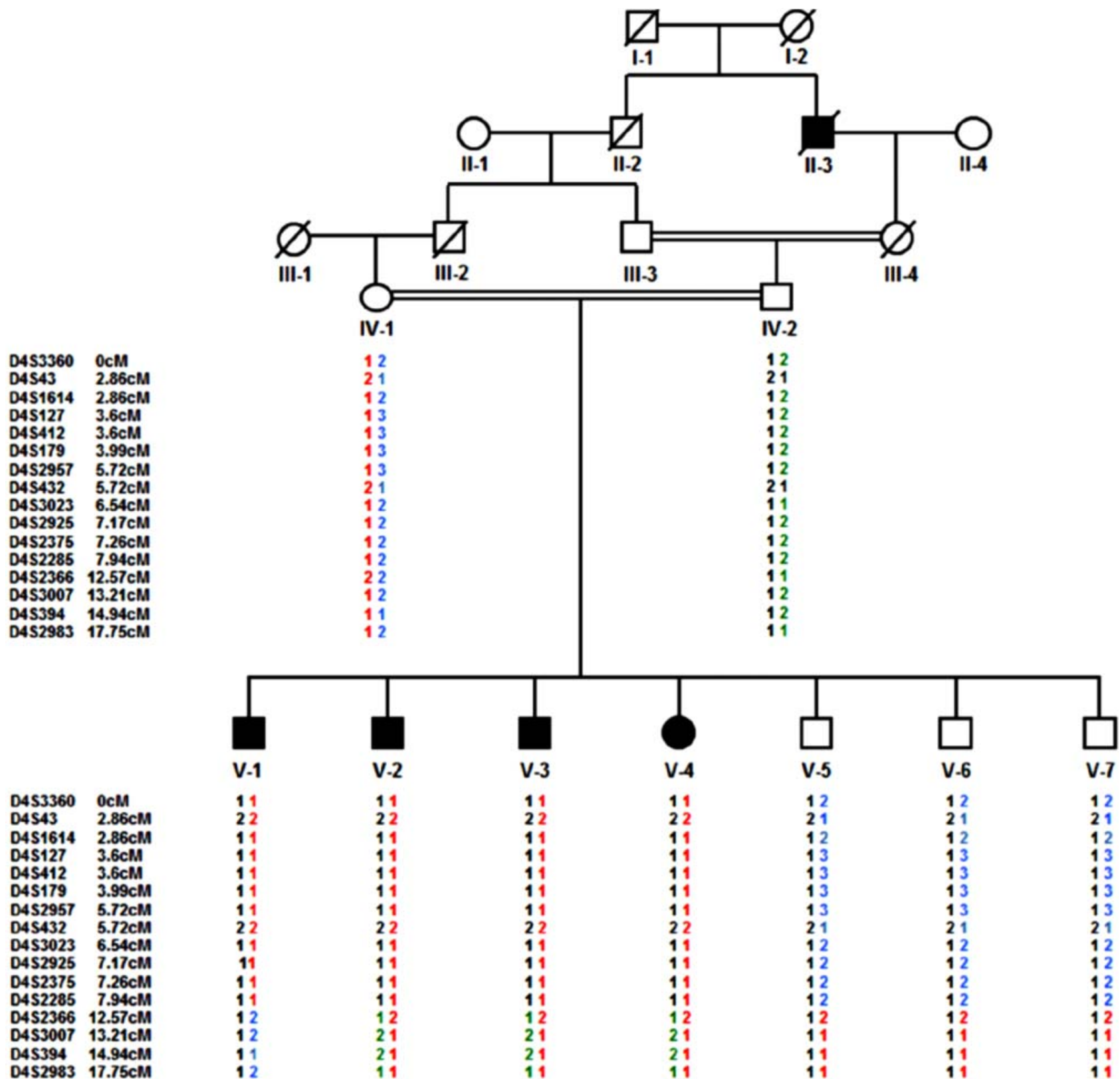

Figure 1 Pedigree of a consanguineous Pakistani family with autosomal recessive postaxial polydactyly type A. Filled and empty symbols represent affected and unaffected individuals respectively. For genotyped individuals, haplotypes of the closely linked microsatellite markers on chromosome 4 p16.1-p16.3 are shown beneath each symbol. Genetic distances in centimorgans (cM) are depicted according to the Rutgers combined-linkage-physical map (build 36.2). ${ }^{20}$ This figure is only reproduced in colour in the online version.

filtered variants were validated by routine Sanger Sequencing in all family members with ABI Prism BigDye terminator cycle sequencing reaction kit (Applied Biosystems, Foster City, California, USA) on ABI3730 Genetic Analyser (Applied Biosystems). Primers to amplify the WES variants were designed using primer3 software $0.4 .0 .^{19}$

\section{Genotyping}

Genotyping using 27 microsatellite markers, selected from Rutgers combined-linkage physical map (build 36.2) ${ }^{20}$ was performed to construct the haplotype. Two-point linkage analysis was carried out using the MLINK programme of the FASTLINK computer package, ${ }^{21}$ while multipoint linkage analysis was performed using allegro V.2. ${ }^{22}$ Mendelian incompatibilities and unlikely genotypes were searched by PEDCHECK and MERLIN, respectively. ${ }^{23}{ }^{24}$ Haplotypes were constructed with the use of SIMWALK2. ${ }^{25}$ Graphical visualisation of haplotypes was performed with HAPLOPAINTERv029.5. ${ }^{26}$

Array comparative genomic hybridisation (aCGH)

Prior to WES, high resolution aCGH (1 M oligo array, Agilent Technologies, Santa Clara, California, USA) was performed in an affected member (V-1) of the family, according to Agilent's protocol (Agilent Technologies, Santa Clara, California, USA). Image data were analysed as described previously. ${ }^{27}$ The pathogenic aCGH findings in this patient were verified by quantitative real-time PCR (qPCR) on ABI prism 7900HT Sequence Detection System, as described by Klopocki et al. ${ }^{28}$ 


\section{RESULTS}

\section{Clinical description}

Affected members of the present family presented bilateral, wellformed duplication of 5 th finger on hands and feet (figure 2A,B). Additionally, the 5th finger was wide and deviated to either radial or ulnar side. However, variable status of this condition was observed among the affected individuals. In an affected individual $\mathrm{V}-1,5$ th finger on the right hand deviated to the radial and on the left hand towards the ulnar side. The 5 th finger on the left hand was wider and more deviated than the finger on right hand (figure 2A). Radial deviation and wideness of only left hand was observed in affected individual V-2 (figure 2C). Another affected individual, V-3, showed only radial deviation of 5 th finger on both hands (figure 2D), whereas wide finger on the right hand and radially deviated 5th finger on the left hand were observed in a fourth affected individual (V-4) of the family (figure 2E).

Radiography of the hands of affected individuals (V-1, V-3) showed, well developed 6th finger joined to the bifid metacarpal bone (figure $2 \mathrm{~F}, \mathrm{G}$ ), radially deviated 5 th finger on both hands of $\mathrm{V}-3$ (figure $2 \mathrm{~F}$ ) and on only the right hand of $\mathrm{V}-1$ (figure $2 \mathrm{G})$. The left hand of $\mathrm{V}-1$ showed duplicated distal phalanx sharing common distal inter-phalangeal joint and small intermediate phalanx of the 5th finger (figure 2G). Duplicated forked shaped 5 th metatarsal bone was observed in radiography of the feet (figure $2 \mathrm{H}$ ).

Teeth, nails, sweating and hearing were normal in all four affected individuals of the family. Neurological problems and facial dysmorphism were not observed in any of the affected individuals. Heterozygous carrier individuals had normal hands

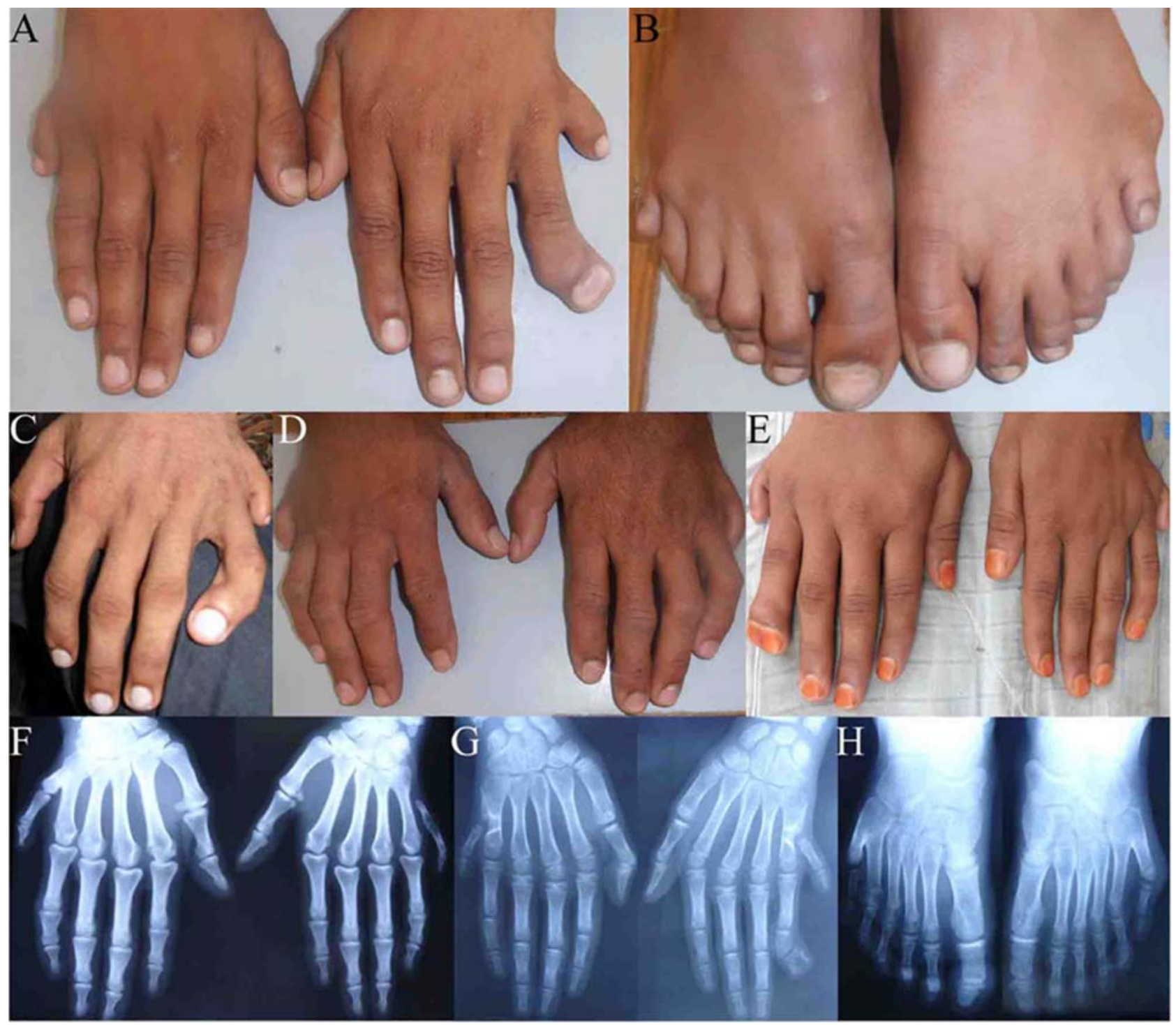

Figure 2 Clinical features postaxial polydactyly (PAP) type A. (A) Hands of an affected individual (V-1) showing well-formed extra digit, radial and ulnar deviations of 5 th finger on right and left hand, respectively and wide 5 th finger on the left hand. (B) Duplicated 5th fingers on feet of an affected individual (V-1). (C) Left hand of an affected individual (V-2) showing radially deviated wide 5th finger. (D) Hands of an affected individual (V-3) depicting radially deviated 5th finger. (E) Hands of V-4, wide and radially deviated 5 th fingers on right and left hand respectively. (F) Hands radiograph of V-3 showing PAP, bifid metacarpal bone and radially deviated 5th finger on both hands. (G) Hands radiograph of V-1 showing PAP, duplicated distal phalanx and small central phalanx of 5th finger and bifid metacarpal bone. $(\mathrm{H})$ Feet radiograph showing fork shaped metatarsal bone and well developed 6th finger. This figure is only reproduced in colour in the online version. 
and feet, and were clinically indistinguishable from genotypically normal individuals.

\section{Filtering of exome sequence variants}

The raw sequence data of all exome sequenced individuals ( $\mathrm{V}-1$, $\mathrm{V}-2, \mathrm{~V}-4$ ) allowed variant calls of high quality for over $90 \%$ of the CCDS exome target region (see online supplementary figure S1). In all three individuals between 23000 and 24000 single nucleotide variants and small insertions and deletions $(<20 \mathrm{bp})$ were detected. Homozygous segments that are shared in all three affected siblings were identified and variants in these segments were filtered for missense, nonsense, frameshift and splice site mutations in GeneTalk ${ }^{18}$ (see online supplementary table S1). All genotypes that were reported with a frequency above 0.001 in dbSNP, the 1000 genomes project or the 5000 exomes project ${ }^{29-31}$ were removed and only 13 mutations remained (table 1). All of these candidate mutations, identified in all three affected subjects, were validated and sequenced by ABI Sanger in the remaining family members. The only variant that cosegregated with the phenotype was a missense mutation in ZNF141, in exon 4 of transcript NM_003441 at c.1421C > T (figure 3). This mutation causes an amino acid exchange of a threonine that is conserved in all primates (figure 4) into an isoleucine. As the mutated threonine is conserved only across the primates, we can conclude that the ZNF141 gene has primate specific function.

The sequence variant c. $1420 \mathrm{C}>\mathrm{T}$ also mutates a recognition site of endonuclease SmoI (see online supplementary figure S2). The loss of this recognition site was used to screen 100 unaffected, unrelated and ethnically matched control individuals and to estimate the frequency of this mutation in the same population background. None of the tested controls showed a loss of this recognition site indicating that c.1421C $>\mathrm{T}$ is a family specific mutation.

\section{Construction of the haplotype}

To construct the haplotype by SIMWALK2, ${ }^{25}$ genotyping was performed using 27 microsatellite markers mapped in the vicinity of the gene ZNF141. Only 16 of these markers (D4S3360, D4S43, D4S1614, D4S127, D4S412, D4S179, D4S2957, D4S432, D4S3023, D4S2925, D4S2375, D4S2285, D4S2366, D4S3007, D4S394, and D4S2983) were informative and considered for further analysis. Analysis of the marker genotypes within this region with PEDCHECK and MERLIN did not detect any genotyping errors. A recombination event between markers D4S2285 (7.94 cM) and D4S2366 (12.57 cM), defined the centromeric boundary of the linkage interval. However no recombination event was observed at the telomeric boundary. The linkage interval flanked by markers, D4S3360 (0 cM) and D4S2366 $(12.57 \mathrm{cM})$ corresponds to $6.53 \mathrm{Mb}$ on chromosome 4p16.1-p16.3, according to Rutgers combined-linkage physical map of the human genome. ${ }^{20}$

The results of the two-point and multipoint linkage analyses are presented in online supplementary table (S2). The maximum two-point Logarithm of the Odds (LOD) score of 2.63 at 0 recombination fraction $(h=0.00)$ was achieved for a markers D4S127, D4S412, D4S179, D4S2957 and maximum multipoint LOD score of 3.38 was obtained with marker D4S412 along the disease interval.

\section{DISCUSSION}

PAP, characterised by fifth digit duplication in hands and/or feet, is a rare anomaly of the hand and foot and often segregates in autosomal dominant manner. In the present study we have presented a family segregating PAP type A in an autosomal recessive manner. Previously, only two families segregating PAP in autosomal recessive manner had been reported. ${ }^{13}{ }^{32}$ Umm-e-Kalsoom et $a l^{13}$ further reported mapping of the PAP type A in their family on chromosome 13q13.3-q21.2. Affected individuals in both of these families had well developed sixth digits. In the family reported by Umm-e-Kalsoom et $a l^{13}$ an additional feature of hallux valgus deformity was observed in one of the affected individual. Affected individuals of the family, presented here, showed well-formed six digits in both hands and feet. This form of autosomal recessive PAP is clearly distinct from the one we described previously, ${ }^{13}$ as it clearly maps in a different chromosomal location. Also, the present study showed a novel phenotype of wide and deviated fifth finger on at least one hand. The wide finger is indicative of duplication of one or all the phalanges of the 5 th finger, as observed in radiograph of an affected individual (V-1) showing duplicated distal phalanx. In families segregating autosomal dominant forms of PAP, affected individuals often shows features representing both type $\mathrm{A}$ and B PAP. ${ }^{8} 10{ }^{11}$ An additional feature of partial cutaneous syndactyly was reported in one of these families which mapped on chromosome $7 \mathrm{q} 21-\mathrm{q} 34 .^{12}$

WES followed by Sanger sequencing of variants identified a missense mutation (c.1420C $>\mathrm{T}$, p.Thr474Ile) in the gene

Table 1 Chromosome wise arrangement of 13 variants identified by whole exome sequencing

\begin{tabular}{|c|c|c|c|c|c|c|}
\hline No & CHR & Physical position & GENE & Type of change & Coding DNA reference sequence & Amino acid change \\
\hline 1 & 1 & 44125966 & KDM4A & Splic-3 & c.315-2delA & \\
\hline 2 & 4 & 367647 & ZNF141 & Missense & c. $1420 \mathrm{C}>\mathrm{T}$ & p.THR474ILE \\
\hline 3 & 4 & 1388625 & CRIPAK & Frame shift & c.325_326dupAC & \\
\hline 4 & 4 & 26737074 & TBC1D19 & Splic-3 & c.1085-2_1085-3insT & \\
\hline 5 & 4 & 40356102 & CHRNA9 & Missense & c. $1005 \mathrm{C}>\mathrm{A}$ & p.HIS335GLN \\
\hline 6 & 4 & 68424629 & STAP1 & Missense & c. $102 C>G$ & p.ILE34MET \\
\hline 7 & 4 & 68619974 & GNRHR & Missense & c. $80 \mathrm{~T}>\mathrm{G}$ & p.ASN27THR \\
\hline 8 & 4 & 70080319 & UGT2B11 & Missense & c. $122 \mathrm{G}>\mathrm{T}$ & p.THR41LYS \\
\hline 9 & 4 & 73943124 & ANKRD17 & Missense & c. $7535 \mathrm{G}>\mathrm{C}$ & p.GLY2512ALA \\
\hline 10 & 11 & 7686606 & CYB5R2 & Frame shift & c.829+1_4dupAACA & \\
\hline 11 & 15 & 101601373 & LRRK1 & Splic-3 & c.4680-3_6dupTTAC & \\
\hline 12 & 19 & 54725913 & LILRB3 & Missense & c. $445 C>T$ & p.GLY149ARG \\
\hline 13 & 19 & 55239176 & KIR3DL3 & Missense & c. $455 \mathrm{G}>\mathrm{A}$ & p.ARG152HIS \\
\hline
\end{tabular}


A TAA GAAAAT T CA TA T T GA GA GAAAT C C TA

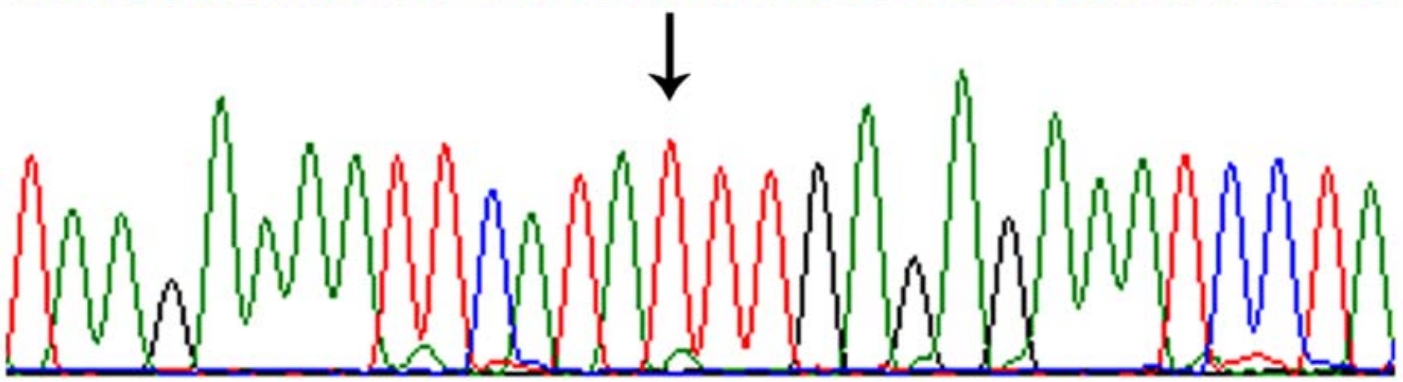

$\mathbf{B}$

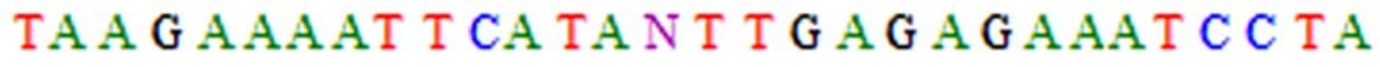

C

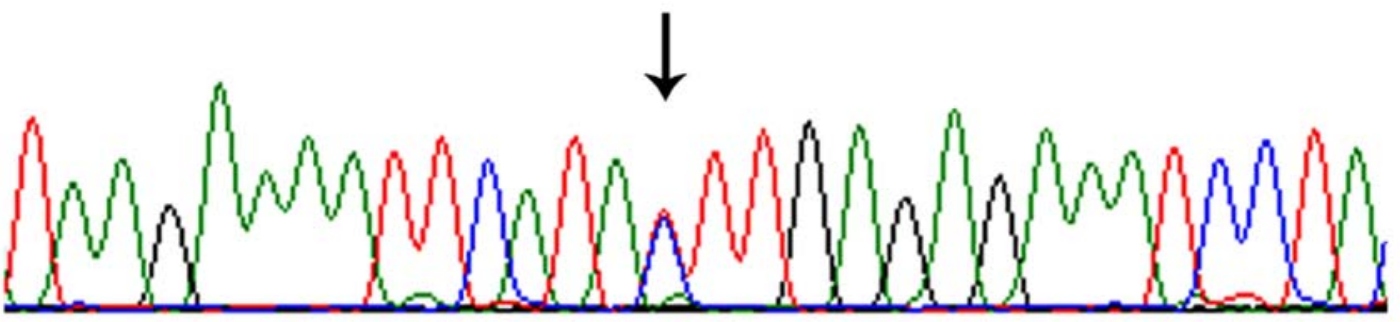

TAA G AAAAT T CA TA C T T G A A GAAA T C TA

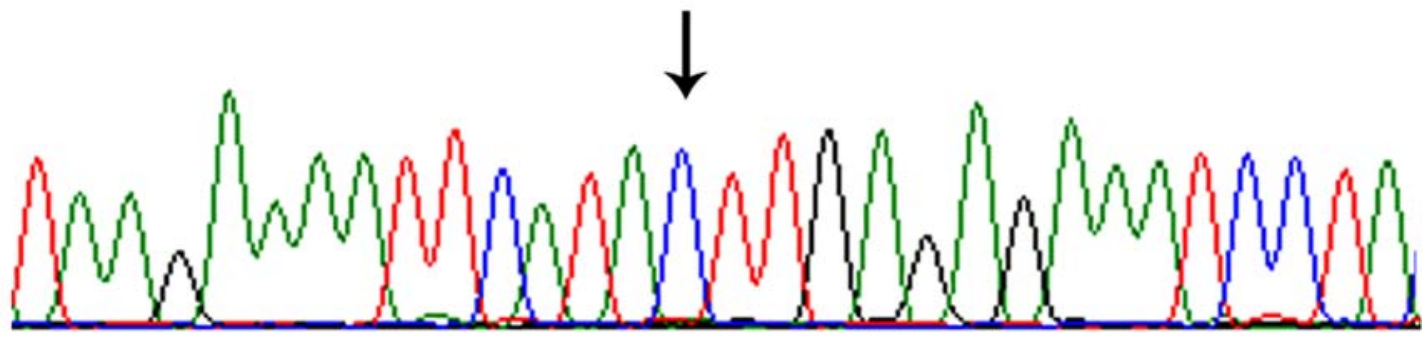

Figure 3 (A) Sequence analysis of a missense mutation (c.1420C>T) in the gene ZNF141 in an unaffected control individual. The middle panel B and the lower panel $C$ represent the sequence in the heterozygous carrier and in the affected individual respectively. Arrows represent position of the mutation. This figure is only reproduced in colour in the online version.

ZNF141, mapped to telomeric region on chromosome $4 \mathrm{p} 16.3$. The mutation (p.Thr474Ile) segregated with the trait in the family and was not detected outside the family in 100 control samples. Moreover, linkage analysis by typing highly polymorphic microsatellite markers established linkage of phenotype to the chromosomal region 4p16.3-p16.1 with maximum multipoint LOD score of 3.38 .

The pathological characteristic of this substitution was further analysed by protein prediction tools, PolyPhen-2 (http://genetics. bwh.harvard.edu/pph/) and SIFT (http://sift.jcvi.org/www/

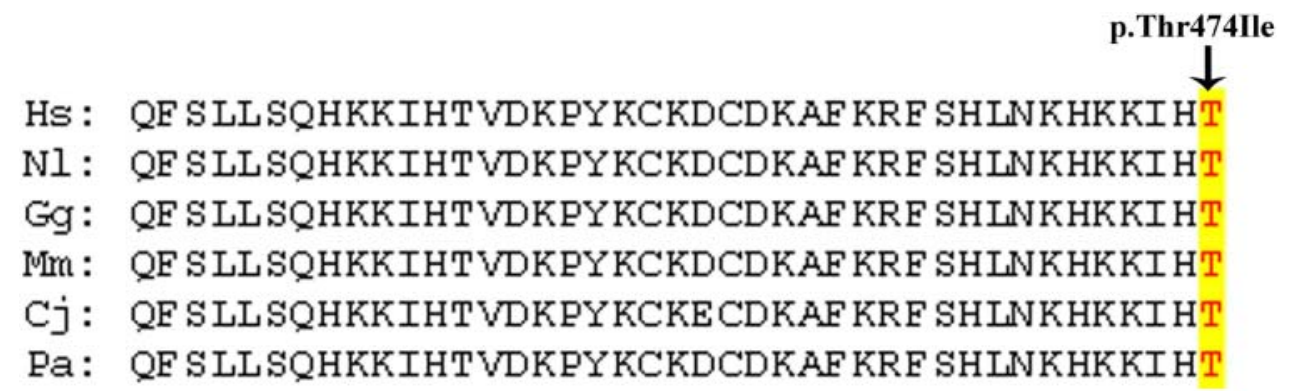

Figure 4 Comparison of Partial amino acid sequence of human ZNF141 with other primates. The shaded threonine (T) indicates the conserved residue across different primates' species. No ortholog was identified in species other than primates, suggesting the primate specific function for ZNF141. The missense mutation (p.Thr474lle) affecting conserved threonine residue in human ZNF141 is indicated by an arrow. Species abbreviations are as follows: Hs, Homo sapiens; Nl, Nomascus leucogenys; Gg, Gorilla gorilla; Mm, Macaca mulatta; Cj, Callithrix jacchus; $\mathrm{Pa}$, Pongo abelii. The Ensemble numbers for respective proteins are as follows: Hs, ENSP00000240499; NI, ENSNLEP00000018568; Gg, ENSGGOP00000009951; Mm, ENSMMUP00000005319; Cj, ENSCJAP00000010026; Pa, ENSPPYP00000016208. This figure is only reproduced in colour in the online version. 
SIFT_seq_submit2.html). Analysis of polyphen-2 (positionspecific independent counts score of 1.000) and SIFT (score of 0.00 ) revealed that the substitution of threonine by Isoleucine (p.Thr474Ile) could probably have a damaging effect on ZNF141 structure thus affecting protein function.

The ZNF141 belongs to the Krüppel (C2-H2) family of zinc finger proteins, having an open reading frame of $1422 \mathrm{bp}$ and encoding a 474 amino acid protein. The encoded protein has a Kruppel-Associated-Box (KRAB) domain, subdivided into box A and box B and 10 zinc finger motifs. Competitive RT-PCR analysis, showed expression of ZNF141 in pancreas, lungs, spleen, liver, kidney, skeletal muscles, testis, brain and placenta. ${ }^{33}$

The $\mathrm{C} 2 \mathrm{H} 2$ zinc finger genes (C2H2-ZNF) make up 2\% of all the human genes and represent the second largest gene family in humans after the odorant receptor family. ${ }^{34-37}$ The $\mathrm{C} 2 \mathrm{H} 2-\mathrm{ZNF}$ proteins often contain an effector domain that is always located $\mathrm{N}$-terminal to the zinc finger region, such as the KRAB, SCAN (SRE-ZBP, CTfin51, AW-1 and Number18 cDNA) and BTB (Broad-Complex, Tramtrack and Bric-abric) domains. $^{38-40}$ The KRAB-associated ZNF (KRAB-ZNF) proteins are specific to tetrapod vertebrates, but the family has expanded dramatically to include hundreds of members in mammals. ${ }^{41-43}$ Huntley et $a l^{44}$ identified $423 \mathrm{KRAB}-\mathrm{ZNF}$ genes and compared human genes with ZNF loci mined from the draft mouse, dog and chimpanzee genomes. Only 103 KRAB-ZNF genes were found to be conserved in mammals and the remaining 136 KRAB-ZNF genes are primates specific, thus providing a clear evidence of lineage specific expansion.

Homology search for ZNF141 (ensemble genome browser), indicates that the substituted threonine residue is conserved across different primates species (figure 4), which suggest that this residue is important for the function of ZNF141. Since no ortholog was identified in species other than primates, we can conclude that ZNF141 has primate specific function and some other gene is performing the same function in other mammalian species. Identification of ZNF141 homologue in mouse, chicken or zebra fish will help to study the normal and abnormal expression of ZNF141 in developing limbs. Also identification of the putative target DNA sequences and the possible role of ZNF141 in transcriptional regulation may enhance the understanding of limb embryogenesis.

Acknowledgements We thank the family members for their invaluable cooperation and participation in this study.

Contributors U-e-K: designed and performed the experimental work, and drafted the article. EK: designed and supervised the experimental work, analysed the data and helped in drafting the article. NW, MT, SK: studied the family in a remote area of the country, collected the samples and performed a part of the experimental work. JH, PK: supervised the experimental work, analysed the data, revised the article critically. SM, WA: Supervised the experimental work, analysed the data, revised the article critically and provided financial support for the research work.

Funding This work was funded by the Higher Education Commission (HEC), Islamabad, Pakistan. U-e-K was supported by an indigenous PhD fellowship from HEC, Islamabad, Pakistan.

Patient consent Obtained.

Competing interests None.

Ethics approval Ethics approval was granted by the Institutional Review Board of the Quaid-i-Azam University, Islamabad, Pakistan.

Provenance and peer review Not commissioned; externally peer reviewed.

\section{REFERENCES}

1 Cohn MJ, Tickle C. Developmental basis of limblessness and axial patterning in snakes. Nature 1999;399:474-9.

2 Cohn MJ. Developmental mechanisms of vertebrate limb evolution. Novartis Found Symp 2001;232:47-57.
3 Blauth W, Olason AT. Classification of polydactyly of the hands and feet. Arch Orthop Trauma Surg 1988;107:334-44.

4 Bellovits 0. Genetical and epidemiological studies of polydactyly in Hungary. Anthropol Anz 2003;61:413-19.

5 Cifuentes L, Nazer J, H€uber ME, Ram_irez R, Nazer C, Morales I. Polydactyly: a genetic epidemiological study in Santiago, Chile. Rev Med Chil 1996;124:313-18.

6 Phelps DA, Grogan DP. Polydactyly of the foot. J Pediatr Orthop 1985;5:446-51.

7 Biesecker LG. Polydactyly: how many disorders and how many genes? 2010 update. Dev Dyn 2011;240:931-42.

8 Radhakrishna U, Blouin J-L, Mehenni H, Patel UC, Patel MN, Solanki JV, Antonarakis SE. Mapping one form of autosomal dominant postaxial polydactyly type A to chromosome 7p15-q11.23 by linkage analysis. Am J Hum Genet 1997a;60:597-604.

9 Radhakrishna U, Wild A, Grzeschik KH, Antonarakis SE. Mutation in GLI3 in postaxial polydactyly type A. Nat Genet 1997b;17:269-71.

10 Akarsu AN, Ozbas F, Kostakoglu N. Mapping of the second locus of postaxial polydactyly type A (PAP-A2) to chromosome 13q21-q32. Am J Hum Genet 1997:6:A265.

11 Zhao H, Tian Y, Breedveld G, Huang S, Zou Y, Chai J, Li H, Li M, Oostra BA, Lo WH, Heutink P. Postaxial polydactyly type A/B (PAP-A/B) is linked to chromosome 19p13.1-13.2 in a Chinese kindred. Eur J Hum Genet 2002;10:162-6.

12 Galjaard RJ, Smits AP, Tuerlings JH, Bais AG, Avella Bertoli AM, Breedveld G, de Graaff E, Oostra BA, Heutink P. A new locus for postaxial polydactyly type A/B on chromosome 7q21-q34. Eur J Hum Genet 2003;11:409-15.

13 Umm-e-Kalsoom Basit S, Kamran-ul-Hassan Naqvi S, Ahmad MW. Genetic mapping of an autosomal recessive postaxial polydactyly type A to chromosome $13 q 13.3-q 21.2$ and screening of the candidate genes. Hum Genet 2012;131:415-22.

14 Pruitt KD, Harrow J, Harte RA, Wallin C, Diekhans M, Maglott DR, Searle S, Farrell CM, Loveland JE, Ruef BJ, Hart E, Suner MM, Landrum MJ, Aken B, Ayling S, Baertsch R, Fernandez-Banet J, Cherry JL, Curwen V, Dicuccio M, Kellis M, Lee J, Lin MF, Schuster M, Shkeda A, Amid C, Brown G, Dukhanina O, Frankish A, Hart J, Maidak BL, Mudge J, Murphy MR, Murphy T, Rajan J, Rajput B, Riddick LD, Snow C, Steward C, Webb D, Weber JA, Wilming L, Wu W, Birney E, Haussler D, Hubbard T, Ostell J, Durbin R, Lipman D. The consensus coding sequence (CCDS) project: identifying a common protein-coding gene set for the human and mouse genomes. Genome Res 2009;19:1316-23.

15 Hercus C. 2011. Novoalign V2.07: http://www.novocraft.com (accessed date June 20 2011)

16 Li H, Handsaker B, Wysoker A, Fennell T, Ruan J, Homer N, Marth G, Abecasis G, Durbin R. The Sequence Alignment/Map format and SAMtools. Bioinformatics 2010;25:2078-9

17 Wabg K, Li M, Kakonarson H. ANNOVAR: functional annotation of genetic variants from high-trhoughput sequencing data. Nucleic Acids Research 2010;38:e164.

18 Kamphans T, Krawitz PM. GeneTalk: an expert exchange platform for assessing rare sequence variants in personal genomes. Bioinformatics 2012; 28:2515-6.

19 Rozen S, Skaletsky H. Primer3 on the WWW for general users and for biologist programmers. Methods Mol Biol 2000;132:365-86.

20 Matise TC, Chen F, Chen W, De La Vega FM, Hansen M, He C, Hyland FC, Kennedy GC, Kong X, Murray SS, Ziegle JS, Stewart WC, Buyske SA. A second-generation combined linkage physical map of the human genome. Genome Res 2007;17:1783-6.

21 Cottingham RW Jr, Jonasson K, Frigge ML, Kong A. Faster sequential genetic linkage computations. Am J Hum Genet 1993;53:252-63.

22 Gudbjartsson DF, Thorvaldsson T, Kong A, Gunnarsson G, Ingolfsdottir A. Allegro version 2. Nat Genet 2005;37:1015-16.

23 O'Connell JR, Weeks DE. PedCheck: a program for identification of genotype incompatibilities in linkage analysis. Am J Hum Genet 1998;63:259-66.

24 Abecasis GR, Cherny SS, Cookson WO, Cardon LR. Merlin rapid analysis of dense genetic maps using sparse gene flow trees. Nat Genet 2002;30:97-101.

25 Sobel E, Lange K. Descent graphs in pedigree analysis: applications to haplotyping, location scores, and marker sharing statistics. Am J Hum Genet 1996;58:1323-37.

26 Thiele $H$, Nürnberg P. HaploPainter: a tool for drawing pedigrees with complex haplotypes. Bioinformatics 2005;21:1730-2.

27 Spielmann M, Reichelt G, Hertzberg C, Trimborn M, Mundlos S, Horn D, Klopocki E. Homozygous deletion of chromosome 15q13.3 including CHRNA7 causes severe mental retardation, seizures, muscular hypotonia, and the loss of KLF13 and TRPM1 potentially cause macrocytosis and congenital retinal dysfunction in siblings. Eur $J$ Med Genet 2011;54:441-5.

28 Klopocki E, Ott CE, Benatar N, Ullmann R, Mundlos S, Lehmann K. A microduplication of the long range $\mathrm{SHH}$ limb regulator (ZRS) is associated with triphalangeal thumb-polysyndactyly syndrome. J Med Genet 2008;45:370-5.

29 dbSNP, short genetic variations. http://www.ncbi.nlm.nih.gov/projects/SNP/ (accessed date June 20 2011).

30 Alshuler D, Durbin RM, Abecasis GR, et al. A map of human genome variation from population-scale sequencing. Nature 2010:467:1061-73.

31 Exome Variant Server. NHLBI Exome Sequencining Project (ESP), Seattle, WA http:/l evs.gs.washinton.edu/EVS/ (accessed date June 20 2011). 
32 Mollica F, Volti SL, Sorge G. Autosomal recessive postaxial polydactyly type A in a Sicilian family. J Med Genet 1978;15:212-16.

33 Tommerup N, Aagaard L, Lund CL, Boel E, Baxendale S, Bates GP, Lehrach H, Vissing H. A zinc-finger gene ZNF141 mapping at 4p16.3/D4S90 is a candidate gene for the Wolf-Hirschhorn (4p-) syndrome. Hum Mol Genet 1993;2:1571-5.

34 Bellefroid EJ, Lecocq PJ, Benhida A, Poncelet DA, Belayew A, Martial JA. The human genome contains hundreds of genes coding for finger proteins of the Krüppel type. DNA 1989;8:377-87.

35 Lander ES, Linton LM, Birren B, Nusbaum C, Zody MC, Baldwin J, Devon K, Dewar K Doyle M, FitzHugh W, Funke R, Gage D, Harris K, Heaford A, Howland J, Kann L, Lehoczky J, LeVine R, McEwan P, McKernan K, Meldrim J, Mesirov JP, Miranda C, Morris W, Naylor J, Raymond C, Rosetti M, Santos R, Sheridan A, Sougnez C, Stange-Thomann N, Stojanovic N, Subramanian A, Wyman D, Rogers J, Sulston J, Ainscough R, Beck S, Bentley D, Burton J, Clee C, Carter N, Coulson A, Deadman R, Deloukas P, Dunham A, Dunham I, Durbin R, French L, Grafham D, Gregory S, Hubbard T, Humphray S, Hunt A, Jones M, Lloyd C, McMurray A, Matthews L, Mercer S, Milne S, Mullikin JC, Mungall A, Plumb R, Ross M, Shownkeen R, Sims S, Waterston RH, Wilson RK, Hillier LW, McPherson JD, Marra MA, Mardis ER, Fulton LA, Chinwalla AT, Pepin KH, Gish WR, Chissoe SL, Wendl MC, Delehaunty KD, Miner TL, Delehaunty A, Kramer JB, Cook LL, Fulton RS, Johnson DL, Minx PJ, Clifton SW, Hawkins T, Branscomb E, Predki P, Richardson P, Wenning S, Slezak T, Doggett N, Cheng JF, Olsen A, Lucas S, Elkin C, Uberbacher E, Frazier M, Gibbs RA, Muzny DM, Scherer SE, Bouck JB, Sodergren EJ, Worley KC, Rives CM, Gorrell JH, Metzker ML, Naylor SL, Kucherlapati RS, Nelson DL, Weinstock GM, Sakaki Y, Fujiyama A, Hattori M, Yada T, Toyoda A, Itoh T, Kawagoe C, Watanabe H, Totoki Y, Taylor T, Weissenbach J, Heilig R, Saurin W, Artiguenave F, Brottier P, Bruls T, Pelletier E, Robert C, Wincker P, Smith DR, Doucette-Stamm L, Rubenfield M, Weinstock K, Lee HM, Dubois J, Rosenthal A, Platzer M, Nyakatura G, Taudien S, Rump A, Yang H, Yu J, Wang J, Huang G, Gu J, Hood L, Rowen L, Madan A, Qin S, Davis RW, Federspiel NA, Abola AP, Proctor MJ, Myers RM, Schmutz J, Dickson M, Grimwood J, Cox DR, Olson MV, Kaul R, Raymond C, Shimizu N, Kawasaki K, Minoshima S, Evans GA, Athanasiou M, Schultz R, Roe BA, Chen F, Pan H, Ramser J, Lehrach H, Reinhardt R, McCombie WR, de la Bastide M, Dedhia N, Blöcker H, Hornischer K, Nordsiek G, Agarwala R, Aravind L, Bailey JA, Bateman A, Batzoglou S, Birney E, Bork P, Brown DG, Burge CB, Cerutti L, Chen HC, Church D, Clamp M, Copley RR, Doerks T, Eddy SR, Eichler EE, Furey TS, Galagan J, Gilbert JG, Harmon C, Hayashizaki Y, Haussler D, Hermjakob H, Hokamp K, Jang W, Johnson LS, Jones TA, Kasif S, Kaspryzk A,
Kennedy S, Kent WJ, Kitts P, Koonin EV, Korf I, Kulp D, Lancet D, Lowe TM, McLysaght A, Mikkelsen T, Moran JV, Mulder N, Pollara VJ, Ponting CP, Schuler G, Schultz J, Slater G, Smit AF, Stupka E, Szustakowski J, Thierry-Mieg D, Thierry-Mieg J, Wagner L, Wallis J, Wheeler R, Williams A, Wolf YI, Wolfe KH, Yang SP, Yeh RF, Collins F, Guyer MS, Peterson J, Felsenfeld A, Wetterstrand KA, Patrinos A, Morgan MJ, de Jong P, Catanese JJ, Osoegawa K, Shizuya H, Choi S, Chen YJ. Initial sequencing and analysis of the human genome. Nature 2001;409:860-921.

36 Messina DN, Glasscock J, Gish W, Lovett M. An ORFeome-based analysis of human transcription factor genes and the construction of a microarray to interrogate their expression. Genome Res 2004;14:2041-7.

37 Schuh R, Aicher W, Gaul U, Côté S, Preiss A, Maier D, Seifert E, Nauber U, Schröder C, Kemler R, Jäckle $H$. A conserved family of nuclear proteins containing structural elements of the finger protein encoded by Kruppel, a Drosophila segmentation gene. Cell 1986;47:1025-32.

38 Bellefroid EJ, Poncelet DA, Lecocq PJ, Revelant O, Martial JA. The evolutionarily conserved Krüppel-associated box domain defines a subfamily of eukaryotic multifingered proteins. Proc Natl Acad Sci USA 1991;88:3608-12.

39 Collins T, Stone JR, Williams AJ. All in the family: the BTB/POZ, KRAB, and SCAN domains. Mol Cell Biol 2001;21:3609-15.

40 Rosati M, Marino M, Franzè A, Tramontano A, Grimaldi G. Members of the zinc finger protein gene family sharing a conserved $\mathrm{N}$-terminal module. Nucl Acids Res 1991;19:5661-7.

41 Bellefroid EJ, Marine JC, Matera AG, Bourguignon C, Desai T, Healy KC, Bray-Ward $P$, Martial JA, Ihle JN, Ward DC. Emergence of the ZNF91 Kruppel-associated box-containing zinc finger gene family in the last common ancestor of anthropoidea. Proc Natl Acad Sci 1995;92:10757-61.

42 Hamilton AT, Huntley S, Kim J, Branscomb E, Stubbs L. Lineage-specific expansion of KRAB zinc-finger transcription factor genes: implications for the evolution of vertebrate regulatory networks. Cold Spring Harb Symp Quant Biol 2003:68:131-40

43 Looman C, Abrink M, Mark C, Hellman L. KRAB zinc finger proteins: an analysis of the molecular mechanisms governing their increase in numbers and complexity during evolution. Mol Biol Evol 2002;19:2118-30.

44 Huntley S, Baggott DM, Hamilton AT, Tran-Gyamfi M, Yang S, Kim J, Gordon L, Branscomb E, Stubbs L. A comprehensive catalog of human KRAB associated zinc finger genes: insights into the evolutionary history of a large family of transcriptional repressors. Genome Res 2006;16:669-77. 


\section{Whole exome sequencing identified a novel zinc-finger gene ZNF141 associated with autosomal recessive postaxial polydactyly type A}

Umm-e- Kalsoom, Eva Klopocki, Naveed Wasif, et al.

J Med Genet 2013 50: 47-53 originally published online November 17, 2012

doi: 10.1136/jmedgenet-2012-101219

Updated information and services can be found at:

http://jmg.bmj.com/content/50/1/47.full.html

These include:

Data Supplement "Supplementary Data"

http://jmg.bmj.com/content/suppl/2012/11/18/jmedgenet-2012-101219.DC1.html

References This article cites 40 articles, 15 of which can be accessed free at: http://jmg.bmj.com/content/50/1/47.full.html\#ref-list-1

Email alerting

Receive free email alerts when new articles cite this article. Sign up in service the box at the top right corner of the online article.

Notes

To request permissions go to:

http://group.bmj.com/group/rights-licensing/permissions

To order reprints go to:

http://journals.bmj.com/cgi/reprintform

To subscribe to BMJ go to:

http://group.bmj.com/subscribe/ 